\title{
Volt egyszer egy Békés-Tarhos
}

\author{
Dévai Adrienn \\ Eötvös Loránd Tudományegyetem Tanitó- és Óvóképzö Kar Ének-zenei Tanszék
}

\begin{abstract}
Absztrakt
1946-ban Énekiskola létesült a Békés megyei Tarhoson, s rövid működése alatt, 1954-es megszűnéséig világhírre tett szert. Összefoglalóm a történeti tényeket tárja fel, az iskola megalakulásától annak megszűnéséig időrendben mutat be történetileg fontos adatokat. Ugyanakkor a tanulmánynak nem célja, hogy a tarhosi iskola legendáját és küldetését bemutassa, nem célja a magas színvonalú és maga nemében egyedülálló zenei képzés részletes prezentálása, az oktatás-nevelés eredményeinek ismertetése. A történelmi háttér rövid áttekintése után a tanulmány kitér az iskola igazgatója, Gulyás György által, a megalakulás körülményinek tükrében megélt „kálváriára”. Az iskola működéséhez szükséges feltételek megteremtése nem volt zökkenőmentes, emellett a kezdetektől kilencéves fennállásáig az itt folyó munka, tanítás mindvégig jelentős nehézségekbe ütközött. A folyamatos teremhiány, a diákok és tanárok elszállásolási gondjai, az élelmezési problémák, a felszereltség hiányosságai mellett politikai támadások, Tarhos jövőjének bizonytalansága is állandó gondokat okozott az iskola igazgatójának, vezetőségének. A nehézségek mellett azonban sok emlékezetes, szép esemény is jutott az iskola falain belül élőknek: A Világifjúsági Találkozó (VIT) koncertje, rádiófelvételek, híres zeneszerzők látogatásai és elismerő nyilatkozatai, a Zenepavilon felépítése, avatása és a koncertre való készülés, Kodály látogatása. Az iskola izgalmas és eseményekben gazdag életét olyan szakirodalmak segítségével dolgoztam fel, mint Csende Béla, F. Pálfy Zsuzsanna, Gulyás György, Gyarmath Olga és Kodály Zoltán munkái. A választott kutatási módszerek a hazánkban megjelent és interneten hozzáférhető magyar nyelvü szakirodalmi források, cikkek és folyóiratok feldolgozásai.
\end{abstract}

Kulcsszavak: Gulyás György, Tarhos, Békés-Tarhos, Énekiskola

1946-ban Énekiskola létesült a Békés megyei Tarhoson, s rövid működése alatt, 1954-es megszűnéséig világhírre tett szert. Az alakulása, fennállása viharos volt, sosem hagyták el a gondok és a nehézségek, ám az iskola falain belül valami olyasmi született, ami addig nem: magas nívójú zenei szakirányú általános iskolai és gimnáziumi képzés.

A tanulmány célja, hogy a korszak rövid történelmi áttekintése után öszszegezze a békés-tarhosi iskolával kapcsolatos eddig fellelhető történeti dokumentumok alapján (Csende, 1976; Gulyás, 1988) az iskola történetét, 
kiegészítve Gulyás György ${ }^{1}$ levelezéseivel, az iskola növendékeinek visszaemlékezésivel, ezzel is új aspektusból megvilágítva az intézmény létezésének körülményeit. A kutatás főként a tartalom- és dokumentumelemzés módszereit használja fel.

\section{Magyarország a második világégés után}

1945. január 20-án Magyarország és a szövetséges hatalmak aláírják a fegyverszünetet és április 13-án befejeződnek a fegyveres harcok Magyarország területén (Romsics, 2010, p. 1006). A háború óriási pusztítást vitt végbe az épületekben, a sínhálózatban, a gyáripari berendezésekben, a marha-, ló-, sertés- és juhállományban, s 900 ezer ember vesztette életét a harcok során (Romsics, 2005, p. 270). De a háború hatalmas károkat okozott a kulturális élet területén is. A kornak megfelelő iskolatípusok (például népiskolák, polgári iskolák, középiskolák) épületeinek több mint felét érte valamilyen épületkár, az osztálytermek romokban hevertek, vagy ablaktalanul várták, hogy elkezdődjön újra az oktatás, ami még 1947-ben is fizikai nehézségekbe ütközött. „Az ország 25-26 ezer tanítója közül 1946 tavaszára még mintegy 2000 nem tért vissza az orosz hadifogságból, 200 Nyugaton maradt, s közel 800 igazolóbizottsági² eljárásra várt." (Romsics, 2005, p. 320).

A háború viszont nem csak rombolt, hanem új energiákat is felszabadított. Elsődleges cél lett a különböző társadalmi hátterű fiataloknak esélyegyenlőséget biztosítani. 1945. április 19-én, az Ideiglenes Nemzeti Kormány ${ }^{3}$, Országos Köznevelési Tanácsot ${ }^{4}$ létesített, amelynek feladata az új, demokratikus szellemü nevelés alapelveinek kidolgozása lett. Az 1940-ben bevezetett nyolcosztályos alapiskola általánossá és kötelezővé tétele központi kérdéssé vált, az új intézménytípus funkciója bővült. Az alsó- és középfokú oktatás egyszerüsödött, kétszintű lett (Romsics, 2005, p. 324). Az 1945-ös évtől kezdődően a polgári iskolákban már nem indítottak új évfolyamokat, helyette - ha nem is mindenütt, de - megkezdődött az oktatás az általános iskolák ötödik osztályában ${ }^{5}$ (Knausz, 1985, p. 8). „1946-ban még csak 816 általános iskola müködött az országban, alig több, mint az összes népiskola

\footnotetext{
${ }^{1}$ Gulyás György (Köröstarcsa, 1916. április 1. - Debrecen, 1993. november 11.) a Békés-Tarhosi Énekiskola igazgatója.

${ }^{2}$ A második világháború után a köz- és magánalkalmazottak háború előtti és alatti politikai nézeteinek és magatartásának vizsgálatára alakult szerv. Az egyes igazolóbizottságok meghatározott fóvárosi vagy Budapesten található országos hatáskörü közintézmények (például minisztériumok) teljes személyi állományát, valamint cégek, magánvállalatok tisztviselő beosztású dolgozóit vonták eljárás alá. http://bparchiv.hu/adatbazisok/igazolobizottsagi-ugyek

${ }^{3} 11$ hónapig (1944. december 21-től) regnált, miniszterelnöke Dálnoki Miklós Béla volt.

${ }^{4}$ Elnöke: Szent-Györgyi Albert. Vezető tagjai többek között: Bay Zoltán, Kodály Zoltán, Illyés Gyula, Ferenczy Béni (Romsics, 2005, p. 321.)

${ }^{5}$ A nevelők és tantermek számáról, tanulók eloszlásáról további értékes adatokat olvashatunk Knausz Imre doktori disszertációjának 9. oldalán (Knausz, 1985, p. 9).)
} 
10 \%-a. [...] Az átalakulási folyamat az 1940-es évek végére fejeződött be." (Romsics, 2005, p. 321). Az új iskolarendszer egy egységes, nemzeti müveltséggel rendelkező generáció kinevelésére jött létre, s az első tanterv 1946 júliusában jelent meg (Romsics, 2005, p.. 324). Jellemző volt, hogy a leghátrányosabb helyzetben lévő térségek (mint tanyák és aprófalvak) tanulóinak a „koalíciós kultuszkormányzat” (Romsics, 2005, p. 321) a napközi otthonok és tanyai internátusok mellett úgy próbált segíteni, hogy elhagyott, vagy kisajátított foúri kastélyokban biztosította a tanulás lehetőségét. Igy rendeztek be tantermeket például Habsburg József föherceg alcsúti palotájában, vagy Parádon a Károlyi és Nagydorogon a Széchenyi grófok egykori lakhelyén (Romsics, 2005, p. 320-323).

\section{A békés-tarhosi kezdetek}

Az iskola alapítója Gulyás György, Törzsök Bélával ${ }^{6}$ folytatott levelezéséből tudhatunk meg sok részletet az intézmény létrejöttének előzményeit illetően: 1945. október 26-i levélből:

„Kné Péterffy Idának írtam (Ének-pedagógiai Szakszervezeti Központ osztályvezetője). (...) Nem tartom célravezetőnek csak általános iskolát nyitni. Ma sem rendelkezünk elegendő szakemberrel, az énektanítás terén. Nekünk, inkább a magasabb zenei képzés megadása a fontos. Viszont a magasabb és alaposabb zenei képzésnek gyökeret, alapot kell teremtenünk már az általános iskolánál, sőt az óvódánál. (...) A következőképpen gondolom:

1./Az állam adná a tanerőkkel való ellátást, a személyzetnek kiadásait, az adminisztrációs ellátmányt, szellemi és tanügyi dolgokkal való felszerelést.

2./A város az otthont, fütést, világítást, a dologi kiadásokat. Ígéret van az internátusi hozzájárulásra is." (Domokos, 2006, p. 7).

Mikor Gulyás György megálmodta az új iskola létrehozásának tervét, a falusi, zeneileg tehetséges gyerekeket akarta megszabadítani a tanyavilág elzártságától, azt szerette volna elérni, hogy a gyerekeknek ne kelljen azt a rögös utat bejárniuk, amit neki kellett ${ }^{7}$ zenei tanulmányai elvégzése során.

„Akkor a levegőben volt valami. A megújulás vágya, a régi kollégiumok, a tehetséges szegény tanulók mentéseinek általánossá tétele, (...) a Bolyai Kol-

\footnotetext{
${ }^{6}$ Törzsök Béla (Battonya 1916. május 11. - Tiszanagyfalu, 2009) karnagy, zenepedagógus.

7 „Homályosan éreztem, hogy a falusi tehetségeket meg kell szabadítani az elzártságtól, a kitaszítottságból eredő hátrányoktól, hiszen hányan tudják azt véghez vinni, amilyen utat nekem meg kellett tennem, hogy zenei pályára kerülhessek?” (Gulyás, 1988, p. 21). Gulyás György négy elemi osztályát a köröstarcsai iskolában végezte, ahol az intézmény harmóniumán próbálgatta ki zenei adottságait, majd a szeghalmi gimnáziumba került, itt két évet tanult. 1929 és 1936 között a Debreceni Református Kollégiumba járt középiskolai tanítóképzős tanulmányai végett, s egy kitűnő énektanárnak köszönhetően megismerkedhetett az akkori kortárs magyar kórusirodalom remekeivel is, mely élmények nagy hatással voltak a későbbi Éneklő Ifjúság debreceni mozgalmának kialakulására is (Kedves, 2004, p. 10).
} 
légium példája, a parasztszármazású értelmiség nevelése az Eötvös Kollégium mellett... $\mathrm{s}$ végül is: a hozzám hasonló sorsok megsegítése, talán inkább mentesítése a hasonló kálváriák alól." (Gulyás, 1988, p.. 21).

Gulyás teljesen Kodály nyomdokain haladva, az ősi pentatóniából kibontakozó magyar zenéjü, magyar anyanyelvü, magyar zenei anyanyelvü, széles látókörü, müvelt, sok ismeretet befogadó, kimüvelt, teljes embert akart nevelni ${ }^{8}$ Átalakította a középiskolai óratervet a zenei képző elvárásai szerint, megtervezte a tanerőkkel való ellátást, sokat tárgyalt levélben és személyesen is, de az Énekiskola ügye nehezen haladt (Domokos, 2006, p. 8).

1946. április 10-én keltezett, szintén Törzsök Bélának írt leveléből úgy tűnik, hogy az álmok nem válnak valóra:

„...Talán tudsz is róla már: az Énekiskola ügye végképp megbukott. Kodály nem egyezett bele a létesítésébe. Röviden vázolom a dolgot: Március 23-tól 25-ig Pesten tárgyaltam Kodály, Ádám, Vásárhelyi, Péterffyékkel. Kodály mereven fogadott, s elég nyersen. Tulajdonképpen nem is fogadott. Ragaszkodott az egyetemi városhoz, az alsó tagozatot nem tartotta fontosnak.

(ÉRTED?!!)

Ma kaptam meg Ádám Jenő levelét: »Kodály főképpen azt emelte ki, hogy az újabb tervek szerint az egyetemi városokban énekszaktanító képzés is lesz, $\mathrm{s}$ így a Zenei Líceum feleslegesnek mutatkozik. « Mit írjak róla többet? Vasárnap indulok haza. Az Énekiskola ügyét pedig lezárom..." (Domokos, 2006, p. 8).

Gulyás György végül mégis kérvényt nyújtott be Emlékirat címen 1945. augusztus 3-án a Vallás- és Közoktatási Minisztériumhoz, melyet Békéscsaba polgármesterén keresztül terjesztett fel Teleki Géza vallás- és közoktatásügyi miniszterhez, egy Békéscsabán létesítendő Énekiskola létrehozásának szándékával (Kedves, 2004, p. 51).

Az Emlékirat a következőket foglalta magába:

Az iskola épületét Békéscsabának kellene biztosítania. A kérvény két tagozat létesítését rögzítette, mégpedig egy nyolc osztályos alsó és egy négyosztályos középfokú szakiskoláét.

Az énekiskolát gyakorlati iskolaként képzelte el.

Zenei gyermekkor ${ }^{9}$ kell a gyermeknek, ezért alsó tagozaton lenne cél a magyar zenei anyanyelv kialakítása, az általános zenenyelv kereteiben, mert „Annak, aki a dúr rendszerben és folyton csak azt szemléltető dallamok közt nevelkedik, az ősi magyar zene iránt nemcsak semmi érzéke nem lesz, ha-

\footnotetext{
${ }^{8}$ „Mit kellene tenni? Az iskolában úgy tanítani az éneket és zenét, hogy ne gyötrelem, hanem gyönyörüség legyen a tanulónak és egész életére beleoltsa a nemesebb zene szomját." (Kodály, 1974, p. 39).

${ }^{9}$ Gulyás úgy képzelte, hogy a gyermek nem csak elméletben tanulná, hanem átélné az ősi magyar gyermekdalok és népdalkincs, valamint a hagyományok világát, így sajátítva el magyar zenei anyanyelvét, mint ahogy kisgyermekkorban beszélt anyanyelvét tanulja. Ekképp adatna meg neki a zenei gyermekkor.
} 
nem azt valósággal csúnyának találja, mint ezt gyakran tapasztaljuk..." (Kodály, 1943, p. 5).

Gulyás az Emlékiratban megfogalmazta az iskola jelentőségét és szükségességét.

A népdal, gyermekdal zenei funkcióján túl, annak nyelvvédő szerepével is indokolta a magyar zenei anyanyelv elsajátításának fontosságát. „A dalban élő sokoldalú nyelvkincs zsenge korban beültetve, $\mathrm{s}$ a dallam segítségével egész életre rögzítve: jobb védelem a nyelvromlás ellen, mint az úgynevezett nyelvvédő könyvek vaskos kötetei." (Gulyás, 1988, p. 24). Az Énekiskola a helyes magyar beszédre, hangsúlyozásra is tanítana tehát, hisz a szöveges dal nemcsak zenéjével hat, hanem szövege rendkívüli hatással van a nyelvi tudatosság megalapozására. Ezen célok megvalósításának szolgálatában állna az iskolai csoportos éneklés, a kóruséneklés, amelyek a társadalmi együvé tartozás fontos állomásai is lennének.

„De mindezeken felül az énekiskola hivatása lenne, hogy zenei önképzőkörök, népi játékok, balladák, mondókák alakítása és meggyökereztetése útján szinte »alapépítkezést« végezzen az egészséges, helyes zenei gondolkodás kialakításához." (Gulyás, 1988, p. 25).

Az énekiskola jelentőségét a vidék és a falu életében, külön szakaszban rögzíti: Gulyás nem véletlenül akarta vidéken megvalósítani iskoláját. A müvészeti cél mellett fontos kultúrpolitikai célt is kitűzött, és olyan muzsikus tanítókat akart képezni, akik az általános iskolákban korszerủen képzett és haladó módszereket alkalmazó ének tanárokként működnének, és egyben a kisvárosok és falvak zenei vezetői is lesznek (F. Pálfy, 2002, p. 14).

Kodály nyomdokain haladva Gulyás vallotta, hogy a magyar népi hagyomány a falu emberének életében él leginkább, ott, ahol a város romboló hatása távol esett. Biztosítani szerette volna a falusi, tanyasi gyermekek részvételét az énekiskolánál, intézményesen, internátusi neveléssel. Úgy gondolta, hogy enélkül a kezdeményezés nélkül, a falusi gyerekek örökké kizárva maradnának a komoly zenei nevelésből, pedig az iskolát éppen őrájuk kellene építeni.

„(...) ne szakítsuk el gyökerétől a növényt, amelyből táplálkozik. Így biztosan izmos fává terebélyesedik, amely bőséges és egészséges gyümölccsel fizet majd az érte hozott áldozatokért, munkáért." (Gulyás, 1988, p. 26).

Gulyás fel akarta kutatni az arra érdemes, fóleg vidéki gyerekeket, hogy biztosítsa számukra a tanulás, zenei képzés, továbbtanulás lehetőségét, ezzel igy vállalva fel ars poétikáját: „vidékről is lehet Európával együtt lépni” (Gyarmath, 2001, p. 25).

Az Emlékirat a tanulók és tanárok kiválogatásáról is szól. Gulyás úgy képzelte, hogy a gyerekek minőségi kiválogatása az alsó tagozaton történhetne meg a tanyák, falvak gyermekei közül, tanítóik ajánlásával. A városok diákja- 
ival kapcsolatban könnyebb, egyszerübb helyzetre számított. Minden gyermek megfigyelésére hosszabb időt tervezett, az Énekiskolában való tartózkodás mellett (Gulyás, 1988, pp. 22-29). A képességvizsgálat követelményeiről nem találtunk fellelhető dokumentumot, azonban a felvételiző gyermekekről és a felvételi pontszámairól Gyarmath Olga ${ }^{10}$ hagyatékában megőrzött néhány feljegyzést. Ezek közül az egyik, egy 1947-es tanulónévsor, mely lista ugyan nem teljes, de abból a felvételiző gyerekek összetételéről kaphatunk információt: a gyermekek legnagyobb része Békés megyei $(77,2 \%)$, de a felvételizők jöttek Csongrádból, Hajdú-Biharból, Jász-Nagykun-Szolnok megyéből, sőt Budapestről és Pest megyéből is. Az elért pontszámok közül a legalacsonyabb 18, míg a legmagasabb - Szokolay Sándor zeneszerzőé, aki a líceum I. osztályába kérte a felvételijét - 36 pont volt (S. Turcsányi, 2011, p. 312).

Gulyás a tanárok kiválasztásánál is a felvétel egyik kritériumaként a szükséges gyakorlati próbát jelölte meg, s minden esetben személyhez kötött választást szorgalmazott. Olyan tanárokat akart, akik hivatástudattal rendelkeznek, szuggesztívek, s már bizonyságot adtak készségeikről (Gulyás, 1988, pp. 22-29).

„A Vallás- és Közoktatásügyi Minisztériumnak, föként magának a miniszternek, Keresztury Dezsőnek, nagyon tetszett Gulyás György előterjesztése, kivitelezhetőnek ítélte meg. Felismerte azt a zenepedagógiai törekvést, amely a lehető legkorszerủbben képes volt megvalósítani azokat az elveket, amelyekért Bartók, Kodály, Ádám Jenő és mások évtizedek óta harcoltak." (Csende, 1976, p. 19).

Az iskola támogatói mellett (mint a Magyar Pedagógusok Szabad Szakszervezete, Keresztury Dezső vallás- és közoktatásügyi miniszter, Nagy Miklós államtitkár, Kerényi György országos énekfelügyelö, Illyés Gyula és sokan mások) bőven akadtak olyanok is, akik ellenezték annak létrehozását. Létesítésével kapcsolatban Kodály is hitetlenkedett. Vajon lehet-e zenészeket, művészeket kinevelni olyan gyerekekből, kiknek nem volt „zenei gyermekkoruk”? - fogalmazta meg aggályát. Kodály „....akkor még fontosnak tartotta a városi zeneiskolák újjászervezését, s ezért ellene volt, hogy Békés-Tarhos egykori szellemi sivatagját oázissal gazdagítva: az ottani kastélyban és körülötte létrehozzuk azt a zenei népi kollégiumot, amely rövid fennállása idején is sok jó példát, kezdeményt és lehetőséget adott zenei életünknek." (Keresztury, 1975, p. 3). Kodály továbbá úgy gondolta, hogy a vidéki gyerekek óriási müveltségi hátránnyal indulnak, így belőlük müvészeket kinevelni egy generáció alatt lehetetlen, ráadásul, a vidéki munkásélet által igénybe vett kéz alkalmatlanná teszi azt a különböző hangszerek kezelésére (Farkas, 2016).

${ }^{10}$ Az Énekiskola egyik tanára, a Tudsz-e Tarhosért lelkesedéssel dolgozni? című, az Énekiskola életét visszaemlékezései nyomán bemutató könyv szerzője. 


\section{Az iskola megalakulásáig hosszú, tekervényes út vezetett, kiterjedt levelezéssel}

Békéscsaba város képviselőtestülete 1945. augusztus 13-án határozatban vállalta, hogy a tervezetben kimunkált alsó és középfokú iskola létesítése esetén az összes dologi kiadásokat és a továbbfejlesztéssel járó költségeket magára vállalja. Azonban Gulyás nem tartotta alkalmasnak a Békéscsaba város által tervezett iskolaépületet, ezért elképzelését Békés község képviselőtestületével is megismertette (Csende, 1976, p. 20).

Debrecen és Eger sem vállalták az iskola alapítását, Tarhos-major pedig először, 1946. július 4-én merült fel mint iskolai helyszín, mikor is két egyetemista, Durkó Mátyás és Tóth János beadvánnyal fordultak Békés község elöljáróihoz, melyben kérték, hogy a tarhosi Wenckheim-kastélyt és a hozzá tartozó parkot az Énekiskola létesítésére ajánlják fel. Nagy Miklós államtitkár, s vele együtt Kerényi György ${ }^{11}$ az énekoktatás országos felügyelője, Tarhosra látogattak és rövid szemle után az ajánlatot elfogadhatónak találták.

Augusztus 26-án Gulyás megkapta a szervezési megbízatást a VKM-től iskolai év előkészítésére, illetve felhatalmazták, hogy a megnyitás érdekében tárgyalásokat folytasson. Ezt követően a földművelési tárca (Országos Földbirtokrendező Tanács - Dobi István) kiutalta a földterületet a Magyar Állami Énekiskola céljára.

Az átadás papíron könnyen ment, de a kastély épületében az UFOSZ (Új Földhöz Juttatottak) tagjai laktak. Gulyás egyedül oldotta meg ezt a felmerülö problémát is. Kikocsizott Tarhosra és ott egy rögtönzött falugyülés keretén belül próbálta siettetni a kiköltözést. Nem volt veszélytelen vállalkozás, hisz akkor egy ilyen gyülésen tartani lehetett a népítélet haragjától. Végül az ott lakók önként távoztak a telekről és épületből, cserébe ígéretet kaptak, hogy gyerekeik is járhatnak majd osztott általános iskolába, ami a helyi római katolikus iskolában meg is valósult (Gulyás, 1988, p. 38).

1946. szeptember 29-én született meg az a költségvetési jóváhagyás, melyben Békés község képviselőtestülete az 1946/47. évi háztartási költségbe beállította a vállalt terhekkel kapcsolatos kiadásokat. A hiteleket engedélyeztetni a belügyminisztériummal kellett, melyre 1946. november 5-én került sor, amikor is kiadták az iskola létesítő rendeletét is (Csende, 1976, p. 28). A létesítő rendelet érdekessége az iskola végleges elnevezésének meghatározása, a tervezett Magyar Âllami Énekiskola helyett Országos Âllami Ének- és Zenei Szakirányú Líceum és Tanítóképző Intézet, Ének- és Zenei Gyakorló Általános Iskola, valamint a képzés különböző évfolyamokra történő engedélyezése (kérelem csak alapiskolára ${ }^{12}$ és középfokú iskolára vonatkozott) (Gulyás, 1988, p 38).

\footnotetext{
${ }^{11}$ Kerényi György Kodály Zoltán tanítványaként Kodály közvetlen köreihez tartozott. A Magyar Kórus Kiadóvállalat (alapítva: 1930) gondozásában megjelent Énekszó és Éneklő Ifjúság folyóiratok egyik alapítója és szerkesztője. Úttörője volt a magyar énekoktatás megreformálásának, népzenei alapokra helyezésének (Parlando, 2018.)

${ }^{12}$ Gulyás György elnevezése, alapfokú iskolára, általános iskolára utal.
} 
A létesítő rendelettel szinte egy időben érkezett meg az iskola helyi tanterve és óraterve is. A közölt, s osztályonként elöírt zenei óraszám az énekés zenei általános iskolában például a következő volt:

$\begin{array}{lr}\text { I. } & 6 \\ \text { II. } & 6 \\ \text { III. } & 6 \\ \text { IV. } & 6 \\ \text { V. } & 8 \\ \text { VI. } & 8 \\ \text { VII. } & 10 \\ \text { VIII.10 }\end{array}$

Ezek megosztása pedig: ének, társas zene, zongora és második hangszer.

A rendelkezésünkre álló dokumentumok közül ${ }^{13}$ két hetedikes órabeosztást tudunk összehasonlítani, melyekből a közismereti tantárgyak eloszlásáról is kaphatunk némi információt. Az egyik egy 1949-es órarend, mely összesen 27 órát irányoz elő a hetedik évfolyamnak, heti hat napban. (1. melléklet) Viszont ebben nem találjuk meg az emelt énekóraszámokat, a táblázatban öszszesen heti 2 énekórát tüntettek fel, alkalmazkodva ezzel az 1945-től működő általános iskolák tantárgyi rendjéhez. Ezen felül heti 5 óra magyar nyelv és irodalom, 1 történelem, 2 földrajz, 3 fizika, 3 számtan, 2 rajz, 2 testnevelés és 3 gazdaságtan (kézimunka) órát találunk beírva az órarendbe, valamint heti 1 óra szabad beszélgetést, 1 vallásórát és 2 óra "Az ember élete” (feltehetően biológia) tantárgyat (S. Turcsányi, 2011, p. 313). Ez az óraelosztás a „normál” általános iskolák 1946-os óratervében foglaltakkal (ahol 26 órát jelölnek meg 7. osztályban - 2. melléklet), óraszám tekintetében majdnem pontosan megegyezik (Surányi, 2005). Az órák elosztásában különbséget tapasztalunk a vallásóra (hit- és erkölcstan), a történelem órák számában; az előbbiből 1 található az Énekiskola órarendjében és 2 a „normál” általános iskolaiban, az utóbbiból pedig szintén 1 az Énekiskola és 2 a „normál” általános iskolai órarendben. Az Énekiskolában, valószínűleg az iskola jellegéből fakadóan, még gazdaságtant is tanítottak, amit a hagyományos általános iskolai órarendben nem találunk.

A másik irat, „Az Országos Állami Ének és Zenei Körzeti Általános Iskola helyi óraterve 1950 évre", melyből a hetedikesek órabeosztását vesszük figyelembe. Ebből kitünik, hogy az énekórák végre nagy számban szerepelnek, heti tíz órában, az alábbi megoszlásban: 4 ének, 2 társas zene, 2 zongora és 2 második hangszeres óra. Itt összességében már 36 órát olvashatunk, a zenei órák mellett magyarból heti 6 , történelemből 2, földrajzból 2, fizikából 4, számtanból 3, rajzból 2, testnevelésből heti 1 órát találunk, valamint továbbra is szerepel az „ember élete” 2 , szabad beszélgetés heti 1 órában és egy „élő idegen nyelv" is, az orosz, heti 3 órában (S. Turcsányi, 2011, p. 313). A nagyszámú tanórákból arra következtethetünk, hogy ebben az időszakban a gyerekeknek már délután is volt iskolai, tantárgyi elfoglaltságuk.

${ }^{13}$ A Békési Jantyik Mátyás Múzeum anyaga. 


\section{Az indulás}

Gulyás jelentette a szegedi tanfelügyelőnek ${ }^{14}$, hogy az intézmény november 7-én megkezdte működését (Gulyás, 1988, p. 41).

Az elhanyagolt, kifosztott épületek helyreállítását, az iskola helységeinek kialakítását Békés község iparosai részben vállalták. Viszont gondokat okozott a müködéshez szükséges teljes költség előteremtése. Hatalmas összefogásra volt szükség az iskola létrejöttéhez, elsősorban olyan alapvető feltételek biztosítása érdekében, mint a tantermek és hálóhelyiségek kialakítása, konyha-ebédlő létesítése, a közlekedés megoldása, a villany, a vízellátás kiépítése, a telefonösszeköttetés pótlása.

A felvételi tájékoztatókat 1946. november 13-án küldték szét az ország különböző iskoláiba. Minden tanulót „hét próbának” vetettek alá, hogy elméleti és gyakorlati módszerrel kipuhatolják, zeneileg mennyire tehetséges. A vizsgálat a tanulók gépies tanulására, kézügyességére, emlékezőtehetségére, előadási érzékére terjedt ki. Három osztályzattal minősítették őket: „kiváló tehetség”, „tehetséges”, illetve „tanításra alkalmas” (Csende, 1976, p. 30-33).

„Dallamot kellett visszaénekelni, ritmust visszakopogni, verset a tanár után egyszeri hallásra visszamondani. Aki akkor ott volt, mindenkit felvettek. Ott is maradtunk, mert elkezdődött a tanítás. Megkezdődött a tarhosi diákéletem, fiatal korom legboldogabb szakasza" - emlékszik vissza a felvételire Bencze László, volt tarhosi diák. Kovácsné Boldis Jucitól pedig a következöket tudhatjuk meg: „Azzal kezdődött a felvételim, hogy az egyik tanár valamit hegedült s nekem játékára körbe kellett járni a termet. Azután kértek, énekeljek valamit. Rázendítettem egy magyar nótára. Nevettek, de segítettek: együtt énekeltük el az Erdő mellett nem jó lakni címủ dalocskát. Ütemet tapsoltak - nekem vissza kellett tapsolnom. Dúdoltak valamit - nekem vissza kellett dúdolnom. Végül xilofonon leütöttek néhány hangot és e hangokat vissza kellett énekelnem. Azonnal felvettek..." (Domokos, 2006, p. 24-25).

A felvételik után elindult a tanítás. A gyerekek beköltöztek a szállásaikra, otthonról hozott ágyneművel, szalmazsákkal. Akinek nem volt, ott készítette el a zsákját:

„,...a gyümölcsösön túl, az erdőszélen volt egy szalmakazal, ott megtömtük szalmazsákjainkat, amelyeket otthonról hoztunk magunkkal, így szereltük fel a vaságyainkat, amelyeket az iskola egy volt katonai kórháztól kapott, és ágydeszkák, netán sodrony helyett fadorongok voltak benne." - vall erről Mező Imre ${ }^{15}$, aki szintén az Énekiskola tanulója volt (Domokos, 2006, p. 46).

${ }^{14}$ Nyéki Ferenc (Szegedi Kis Újság, 1946. 08. 15.)

${ }^{15}$ A tarhosi Énekiskola növendéke. 1932-ben született, később zeneszerző lett. 
Az iskolaavatásra 1947. február 15-én került sor. Akkora az oktatás már kialakult tanítási rend szerint folyt, illetve az iskolai kórus is el tudta énekelni a régi iskolás gyerekek dalát és annak Kodály szerinti feldolgozását, a Gergelyjárást. Az intézet 7 fős tantestülettel (Gulyás György, Gráf Ottó, dr. Homér Janka, Kapás Géza, Mánya Éva, Molnár Teréz, Ruber Katalin), 63 általános iskolai és 10 líceumi növendékkel kezdte meg müködését a tarhosi Wenckheim birtokon. Megszületett tehát az első zenei szakirányú középiskola és tanítóképző intézet (líceum érettségi lehetőségével is) és a vele kapcsolatos ének és zenei általános iskola. Megnyitásra került az általános iskola 1-6. osztálya és a líceum I. osztálya (Gulyás, 1988, p. 39, 46; F. Pálfy, 2002, p. 15).

Az első iskolai évben a Magyar Kommunista Párt részéről is találtak pártfogókat. Keleti Ferenc az MKP Békés megyei bizottságának titkára sokat segített, hogy a nehézségekkel küzdő iskolában a problémákra megoldást találjanak. Keleti tájékoztatást kért Gulyás Györgytől az intézet helyzetéről, hogy illetékes helyeken a megfelelő információk birtokában támogatni tudja az intézményt, ezzel is segítse a gondok elhárítását. Gulyás súlyos problémákat ecsetel a jelentésében; „5 tanterem, 2 tanulóterem, 3 hálóterem, 2 mosdóhelyiség, $5 \times 2$ szoba tanári és tanítói lakás a minimum, amire szükség van, ezek nélkül az iskola tovább nem fejleszthetőo" - írja (Csende, 1976, p. 48).

Az iskolai alkalmazottak és tanulók lakhatási körülményei kritikus épülethiányról tanúskodtak. Tanárok és tanítók hárman-négyen laktak egy szobában, $\mathrm{s}$ a tanulók hálóterme is túlzsúfolt volt, állandó hatósági kifogás alá esett. A fiú tanulók az iskolától mintegy másfél kilométerre laktak, ivó- és mosdóvizet kilométerekről hordtak, de étkeztetésük az intézetben történt (Csende, 1976, p. 48). Mező Imre emlékeiből a következő kép rajzolódik elénk:

„47 szeptemberében a fiúkollégium az ún. »intézői lakás«-ban volt elhelyezve, néhány szobában. Pár hét múlva azonban ezeket a szobákat az Intézet más célokra vette igénybe, ettől kezdve aztán a berkei vadászkastély lett a szállásunk. A nagy teremben a kisebb fiúk laktak, földszintes ágyakon, a két kisebb szobában a nagyobbak, az elsős és másodikos licisták laktunk, emeletes ágyakon aludtunk.

Vízvezeték nem lévén, egy lajttal keskenyvágányú vasúton húzták az épület mellé a vizet. Ehhez a leágazást mi magunk készítettük el: minden előzetes hozzájárulás nélkül, beépítettünk egy váltót a Sarkadi Cukorgyár vonalába, így vezettük a vágányt a kollégiumig. A kályhákban egy altiszt rakta a tüzet, kályhán melegített vízzel, lavórokban mosakodtunk. (...)

Reggeli előtt és vacsora után lórén vittek be minket a majorba, vagy a Nagykastélyhoz és onnan vissza a kollégiumba. A lóré egy, a kisvasúton a cukorrépa szállítására rendszeresített nyitott, magas oldalú teherkocsi volt, ülések és tető nélkül." (Domokos, 2006, p. 48). 
Fejes Antal ${ }^{16}$, volt tarhosi diák, csellóművész pedig így emlékszik vissza: „A mai elvárásokhoz képest elég mostoha körülmények között laktunk. A lányok a kastélyban, a fiúk a 2 km-re fekvő Berkében, egy egyszerü kollégiumban. Szalmazsákon aludtunk, egy hálóban 20-25-en. Egy héten egyszer volt meleg vizünk. Reggelire gyakran rántott-levest kaptunk, néha hoztak a Nyírségből egy nagy teherautóval almát. Pillanatok alatt szétkapkodtuk. Megtanultuk becsülni az értékeket." (Dombi, 2016).

Június 25-én megtartották az első tarhosi évzárót.

\section{Zenei nevelés}

Az énekes alap bevezetésének kísérlete volt a tarhosi iskola zenei nevelésének legjellemzőbb oldala. Azt vallották, hogy mindenféle zenélés, hangszertanulás fundamentuma az éneklés, de fontos helyet kapott a szolmizáció megtanítása is, ami akkoriban nem volt általános. A kottaolvasás Tarhoson a szolmizálás megtanulásával kezdődött, amíg a zenei írás-olvasást a gyerekek el nem sajátították. Ez. 2-3 évig tartott, s utána intenzíven tértek át az abszolút nevek olvasására. A szolmizáció a továbbiakban, mint mankó szerepelt, s csak akkor került elö, ha erre tényleg szükség volt egy nehezebb dallam eléneklésénél (Gulyás, 1988, p. 62).

Fejes Antal visszaemlékezéséből a következőket tudhatjuk meg: „1950-54ig, az iskola váratlan megszünéséig lehettem a tarhosi iskola diákja. Édesapámék vittek el a felvételire 8 éves koromban, tarhosi tanáraim és Gulyás György pótolták azt a sok szeretetet, amit előzőleg otthon a szüleim nyújtottak nekem. Az akkori időkre visszaemlékezve a tudást említem először, amit Tarhoson kaptunk. Először mindenki énekelni tanult, a szolmizálással anyanyelvi szinten éltünk. Napi táplálékunk volt Bertalotti Ötvenhat solfeggio-ja, Kodály 55 kétszólamú énekgyakorlata és a Biciniumok. Az Énekiskola a kodályi elvet követte: »Addig senki ne vegyen hangszert a kezébe, amíg nem tud énekelni. « Akinek valamilyen okból nem vált be egy hangszer, a tanárok rugalmasan váltottak másikra. Édesapám vágyát teljesítve akkor én is hegedülni tanultam, s csak az iskola megszűnése után győzte meg édesanyámat Friss »Tóni bácsi«, hogy szívesen felvenne Békéscsabán, a növendékei sorába. Hálás vagyok érte mindkettőjüknek. Így lettem csellista." (Dombi, 2016).

A líceumi órabeosztásról és tananyagáról Mező Imre visszaemlékezéséből informálódhatunk: „Tanulmányainkról szólva elsősorban a zenei órák nagy számára emlékszem. Ének-gyakorlat, zeneelmélet, zenetörténet, szolfézs, társas zene szerepeltek a tanmenetünkben, illetve a tantárgyaink között, a kóruséneklés mellett. Az összes addigi elkészült Kodály művet beszereztük és végig-énekeltük: a 333 olvasógyakorlatot, a Bicinia Hungarica négy füzetét (főleg az elsőt és a negyediket), az Ötfokú zene négy füzetét, a

\footnotetext{
${ }^{16}$ A Békés-Tarhosi Énekiskola egykori tanulója (1950-1954-ig), a Békési Zeneiskola igazgatója (41 éven át), a Békés-Tarhosi Zenei Napok művészeti vezetője (9 évig, 2006-os nyugdíjba vonulásáig). https://www.parlando.hu/2015/2015-6/Bekesi_Zeneiskola_jubileuma.htm
} 
15 kétszólamú énekgyakorlatot, és használtuk az Énekeljünk tisztánt is. Tanulmányaink alaposan végigdolgozott témája volt Bertalotti: 56 solfeggio-ja. Jóformán kívülről tudtuk ezeket..." (Domokos, 2006, p. 56).

„Tarhosi mindennapjainkat reggeltől estig áthatotta a népdal. Énekeltünk a zenei órákon, a kóruspróbákon, a táncok gyakorlásakor; szabadidőben a kastély körül a parkban, vagy ha közös kerti munkát végeztünk, ha építkezésekhez téglát pucoltunk. És egyfolytában énekeltünk népdalokat akkor is, amikor egy-egy szereplésre utaztunk." - tudjuk meg Bencze Lászlóné Mező Judittól, aki Tarhos diákja volt szintén (Domokos, 2006, p. 74).

Az iskolai oktató-nevelő munkán túlmenően, úgynevezett népfőiskolai jelleget is meg akartak valósítani Tarhoson Gulyásék, dán és sárospataki ${ }^{17}$ mintára. Igy történt, hogy már az első nyáron megnyitotta kapuit az országos szabadmüvelődési tanfolyam, 1947. július 1-5. között. Az elhelyezési viszonyok, rossz és szűkös hálókörülmények miatt sok panasz érkezett a tanfolyamot követően Gulyáshoz, a bátyjához és a központi vezetőkhöz is (Gulyás, 1988, p. 45).

A tanfolyamot 1951-ben megszüntették.

Távlati tervek között szerepelt, hogy a tarhosi iskola olyan felkészültségi szintet biztosítson a tanulóknak, hogy az ott szerzett érettségivel még akkor is el tudjanak helyezkedni, ha zenei pályájukban törés következne be. A tervezett, úgynevezett pavilonok építése is ezt a célt szolgálta volna. Pavilonrendszert képzeltek el, volt irodalmi pavilon, természettudományi pavilon, zenepavilon, illetve testnevelési pavilon az iskolai fóépület és a kollégium épületén kívül.

A pavilonok összekötését egy úgynevezett nyak-tag oldotta volna meg.

Az ország, de akár egész Európa legszebb zenei intézményévé válhatott volna a tarhosi iskola (Gulyás, 1988, p. 40).

A második tanév (1947/48) már teljes tantestülettel indulhatott: Gulyás György, Domonkos Géza, dr. Homér Janka, Mihály Margit, Nemcsik Lehel, W. Sípos Éva, Varga Klára, Gyarmath Olga, Jantos Lajos, Kapás Géza, Mánya Éva, Molnár Teréz, Pálfi Irén, Soós István és dr. Szabó Lajos (F. Pálfy, 2002, p. 15). Ez a tanév olyan eredményeket hozott, amely az ország érdeklődését Tarhos irányába fordította: A tarhosi gyermekkórus ekkor kezdett az orszá-

\footnotetext{
${ }^{17}$ A Sárospataki Népfőiskola megnyitása, Dr. Szabó Zoltán (1902-1965) nevéhez füződik, aki 1935. június 13-án javasolta, hogy a következő években nyíljon meg egy népfőiskola a környék református parasztifjúsága számára. A javaslat elfogadásra került és az intézmény egészen 1948-ig működött, mikor is a kormányzat egy tollvonással megszüntette a népföiskolák működését. A népfőiskola hívő embereket akart nevelni, szakismerettel bíró fiatalokat, akik ismerik falujuk múltját, gyökereit, szokásait. Az iskola célkitűzései a nevelés terén harmonizáltak a 30-as, 40-es években a parasztság hivatásáról kialakult elgondolásokkal:

- a magyar népi kultúra megőrzése és tovább építése,

- mezőgazdasági kultúra megteremtése,

- a parasztság fundamentális szerepének felismerése a nemzet életében (Horváth, 2002).
} 
gos vérkeringésbe bekapcsolódni ${ }^{18}$. Gulyás György naponta (a vacsora előtt) 5 órától 7-ig tartotta a kóruspróbákat. Ha egyéb elfoglaltságai miatt ezt a feladatot nem tudta ellátni, úgy lelkes segítőtársa, Holló Sándor dirigálta a gyerekkart. A tarhosi kórus 6-18 éves, vagyis általános és középiskolás lányok alkotta egynemükar volt, melyben mutált hangú fiúk is énekelhettek nem reprezentatív alkalmakkor, duplázva az alsó szólamot, egy oktávval mélyebben.

Házilag került sor a világítás kiépítésére és a víztorony működtetésére (Gulyás, 1988, p. 48). Az intézet azonban élelmezési gondokkal küzdött. Ezt Mezö Imre tollából így ismerjük meg:

„Kapás Géza ismertette velünk az iskolai illetve kollégiumi élet rendjét: reggeli után a tanítási órák következnek, utána ebéd, de nem maradunk éhen közben sem, mert a 'nagyszünetben' - ez 15 perces volt, a második óra után - 'uzsonnázunk is', mondta., (...) sajnos ez csak fél évig tartott, utána beszüntették az uzsonnáztatást, nyilván élelmezési nehézségek miatt. Ilyen pedig valóban volt, főleg 47-ben és 48-ban: reggelire feketekávét kaptunk, vacsorára puliszkát (ez főtt kukoricalisztből készült) tejjel. 49-től kezdve aztán fokozatosan javult az ellátásunk." (Domokos, 2006, p. 54).

Szokolay Sándor pedig ekképp emlékszik vissza a nehézségekre szüleinek küldött leveleiben: „A reggeli például egy bögre tej, s az ebéd 2-kor van. Bizony, addig jól megéhezünk, mert az említett tízóraiból még nem kaptunk semmit.” (Szokolay, 2017, p. 26). „Többek között az iskola egyelőre (nem véglegesen) csak 2000 forintot kap egyhavi élelmezésre az államtól, meg a beadott természetbeli áll a rendelkezésünkre. (...) Ez nagyon kevés. Hisz maga a tej havonként 1800 forint, így mától kezdve csak vasárnap kapunk tejet. Helyette tea, fekete (pótkávé, tej nélkül) vagy köménymagleves lesz. Másodszor azt is tudjátok, hogy a kenyérfejadag országosan csökkent. Már oly kevés, hogy egy napra alig tudják elosztani. Lehet, hogy mindenkinek kiadják reggel az egynapi fejadagot, s ki hogy akarja, ossza be magának. Ezért kérlek benneteket, hogy egy veknit küldjetek minden héten, anélkül is, hogy írnék." (Szokolay, 2017, p. 37).

A Szegedi Tankerületi Főigazgatóság 1948. április 12-14 között látogatást tett az iskolában, Kollár Pál, a szegedi zenekonzervatórium igazgatója és Szeghy Endre polgári iskolai tanárképzős főiskolai tanár személyében. A szakmailag pozitív eredményeket hozó, jól sikerült látogatás folyományaként jegyzőkönyvben rögzítették és javasolták Tarhoson hangszeres magánvizsgák tartását, a Zeneakadémiáról kiküldött vizsgaelnök jelenlétével. Ezt kérelemben terjesztették fel Gulyásék április 27-én az illetékeseknek, de soha nem érkezett rá válasz.

\footnotetext{
181948 tavaszán a centenáriumi rendezvénysorozat keretében már szerepelt a Békés-Tarhosi Gyermekkórus a Zeneakadémián. Kodály Zoltán kezdte figyelni a korábban „elvetélt gondolat"-ként aposztrofált iskolát (Gulyás, 1988).
} 
Kollár Pál és Szeghy Endre látogatása és pozitív véleménye sokban segítette Alexits államtitkár döntését, miszerint az iskola neve (típusa) 1948 őszétől: kísérleti ének- és zenei középiskola (gimnázium), körzeti ének- és zenei általános iskola (Gulyás, 1988, pp. 52-53).

Az iskolát kétévenként szervezték, az átszervezések pedig megváltoztatták az iskola típusát; a líceumi és tanítóképző intézetből (1946-1948) kísérleti ének- és zenei középiskola (gimnázium) és körzeti ének- és zenei általános iskola lett (1948), ezt követően zenei szakirányú gimnázium (1948-1951). Egyben engedélyezték az egyéves énektanító-képző tanfolyamot (1950), majd zeneművészeti szakközépiskola és zenei gimnáziummá nyilvánították (1952-1954). Egyedül az általános iskola típusa maradt érintetlen, bár „gyakorló iskolából" körzeti általános iskola lett (Gulyás, 1988, p. 51).

\section{A termelöszövetkezet}

Gulyás 1948 áprilisában javaslatot tett arra, hogy az iskolát, kollégiumával együtt alakítsák át, termelőszövetkezetté. Olyan szövetkezetté, amelyik egy teleppel mint kollégiummal azt jutalmazza, aki a legtöbb egyéni vagy közösségi-szellemi vagy fizikai munkateljesítményt mutatja fel. „Nem a mai szervezetből indultam ki. Egyszerűen abból, hogy szervezésében, munkamoráljában, munkaerkölcsében éppen azt 'céloztam' meg, hogy a gyerek már az iskolában elsajátítsa azt az életformát, ami majd 'kinn' a társadalomban várja." (Gulyás, 1988, p. 53). Úgy gondolta, hogy így a szellemi és fizikai munka a legjobban, közösen értékelhető.

Gulyás visszaemlékezése szerint, iskolai események voltak ennek a javaslatnak az előzményei: A gyerekek, ha kellett, konyhakertészettel is foglalkoztak és versenyeztek, hogy kinek terem szebben és többet a veteményese.

Egy alkalommal pedig Szokolay Sándor, Mező Imre és Bencze Laci mentek be Gulyáshoz, hogy gyakorlószobákat kellene építeni. Egy régi istállóépületet néztek ki az átalakítás céljára, ahol talán négy gyakorlóhelyiséget is ki lehetett alakítani. Gulyás a megyétől kerítette hozzá a meszet, a bontási téglából ők megcsinálták az épületet. Ez is sokat nevelt.

A gyerekek keze munkájának volt köszönhető a salakút is a „nagykastély” mellett, de a kisinternátus mögötti Zongoraház felépítése is a diákok közreműködésével született meg. Egy romos ólat tettek rendbe és toldottak meg pár szobával és egy folyosóval egy ács és egy kőműves vezetésével, akiket Gulyás szerzett, ahogy téglát, meszet és cserepet is. Ilyen előzmények folyománya lett tehát a termelőszövetkezet alakítására tett javaslat (Gulyás, 1988, pp. 53-56).

Gulyásnak határozott elképzelései voltak a termelőszövetkezettel kapcsolatban:

Úgy gondolta, hogy az iskola teljes vagyonával egy független, szövetkezeti alapot kell, hogy képezzen. Az egyedüli értékteremtőként a szellemi és fizikai munkát, az egyén munkáját jelölte meg, amit a tanuló és tanár maga teremt, 
egyre inkább bővülő kulturális igényeinek megfelelően. A szövetkezet feladata az iskola szellemi irányítása: könyvek vásárlása, könyvtár szervezése, szellemi továbbképzés, hanglemezek, hangszerek vásárlása, hangversenyekhez műsor összeállítása.

A diákság részt vesz a szövetkezet megszervezésében, később annak müködéséhez szükséges minden részében: az irányításban, a munka kiértékelésében, az adminisztratív vezetésben. A szövetkezet diákságának feladata, hogy irányítsa az iskolán kívüli munkák, mint például kirándulások, hangversenyek megszervezése, valamint közösségi tanítás, például előadások megszervezését, lebonyolítását.

A szellemi és fizikai munka értékelését ugyanazokkal az eszközökkel képzelte, úgy vélte, ennek nevelő hatása lesz mind a diákság, mind a tanárok között. Úgy gondolta, hogy a tanuláson, gyakorláson kívül végzett munkát mindenkinek el kell ismernie.

Gulyás a termelőszövetkezet létrejöttéhez minden szükséges lépést megtett. Felvette a kapcsolatot a Magyar Országos Szövetkezeti Központtal, ahonnan biztatást és segítséget kapott. Ennek alapján elkészítette az alapszabályt, s 1948. május 22-én megalakította a termelőszövetkezetet. Viszont a VKM ${ }^{19}$-től a szükséges hozzájárulást és engedélyt nem kapták meg (Csende, 1976, p. 51-53).

\section{A fejlesztések}

Az iskolát - amely az 1948/49-es, harmadik tanévtől, mint országos állami ének-zeneiskola és zenegimnázium müködött - több alkalommal át akarták költöztetni más településekre.

Gulyás 1948-ban már egyre nehezebben tudta elképzelni az olyan helyszínre való költöztetést, ahol a „telepszerü” elrendezés (együtt kollégium, iskola és zenei rész) nem biztosított. Gyula, Békéscsaba és Pannonhalma után még Miskolc is szóba került, mint a költözés lehetséges célállomása, de aztán 1949. első felében a VKM végleges döntést hozott afelől, hogy az iskola Tarhoson marad (Gulyás, 1988, p. 58).

Az 1948-as esztendő sok változást hozott. A tanári kar létszáma bővült, az iskola önálló hangversenyt adott s a szükös elhelyezés - amely vonatkozott éppen úgy az iskolai tantermek számára, mint az internátusra, vagy a tanárok lakásgondjaira - enyhült, mikor is sikerült egy 4 tantermes kisiskolát felépíteni, az elbontott villanytelep és a mellette lévő romos istállónak a helyén. Az Országos Tervhivatal kiutalt százezer forintot, hogy a bontási téglából építkezni tudjanak. A Békéscsabai Építő Nemzeti Vállalat és a tarhosi iskola gyerekei közremüködésével meg is indultak az építkezések. A negyedikeseket, a sok tanulásra való hivatkozással mentesítették a munkák alól (Szokolay, 2017, p. 141).

Gulyás így emlékszik vissza az időszak eseményeire: „A tégla helyszínre fuvarozását mi magunk vállaltuk. Ez azt jelentette, hogy esetenként egy-egy

${ }^{19}$ Vallás- és Közoktatásügyi Minisztérium 
osztály ott tevékenykedett, egyik óra alatt megrakták a teherautót, addig én tanítottam, majd a szünetben az autóval a helyszínre fuvaroztam a rakományt $\mathrm{s}$ visszatértem tanítani. A tanulók pedig lerakták a téglát a kijelölt helyre.

Meglepően hamar felépült az épület. Még tanári szobát is alakítottunk ki az új épületben." (Gulyás, 1988, p. 58.).

Ekkortájt került sor egy tehergépkocsi beszerzésére is, s ugyan az iskolának csak előlegre futotta, a szülői munkaközösségnek sikerült megvásárolnia a jármüvet.

„Álló nap festettem az iskola teherautójának oldalára a kilométeres címet: Országos Âllami Ének- és Zenei Szakirányú Líceum és Tanítóképző Intézet Békés-Tarhos. Mikor a járó-kelő békésiek meglátták, csak annyit mondtak: itt a zenés autó!" - osztja meg gondolatait Bencze László, volt tarhosi diák. (Domokos, 2006, p. 52).

Bár az Énekiskola folyamatosan küzdött fennmaradásáért, az 1948-as esztendő a kibontakozás időszakának is a kezdete volt. Az iskola tekintélyének növekedését mutatja, hogy „Czövek Erna ${ }^{20}$ a Kultuszminisztérium művészeti osztályának munkatársa elrendelte, hogy az országból az összes zeneiskolai igazgatók és zeneelmélet tanárok idejöjjenek Tarhosra, tanulmányútra." (E. Kovács, 1949, p. 75).

1948 végén már a kollégium bővítésére, az iskolatermek építésének megkezdésére is sor kerülhetett és sikerült néhány új gyakorlófülkét is kialakítani. Szokolay Sándor levelezéséből a következőket tudhatjuk meg: „December 6-án avatási hangversenyt tartunk, ugyanis elkészültek a zongorafülkék. Öt gyakorló van, mely öt zeneszerző nevét viseli. Beethoven, Mozart, Bach, Bartók és Kodály. A műveikből lesz összeállítva a műsor. Két darabot én is fogok zongorázni: Bachot és Bartókot. nagyon nívós műsor lesz. Meghívjuk Ortutay Gyulát és egypár zeneszerzőt." (Szokolay, 2017, p. 94).

1949-ben Budapesten szerveztéka Világifuúsági Találkozót (VIT), ahol a Tarhosi Gyermekkar - egy mikosdpusztai felkészítő táborozást követően nagy sikerrel szerepelt, ősszel pedig már rádiófelvételük volt (Gulyás, 1998, p. 64). Még ebben az évben, az akkori vallás- és közoktatásügyi miniszter (Ortutay Gyula) elkalauzolta a Magyarországra érkezett szovjet politikai és kulturális delegáció két tagját Tarhosra, Novikov zeneszerzőt és Szvesnyikov kiváló kóruskarmestert. Novikov később igen elismerően nyilatkozott az ott tapasztaltakról, illetve visszatérve Moszkvába, a Szovjeckájá Muzikában is írt egy cikket Tarhosról. A szovjet zeneszerzők lapjában megjelent cikk fordítása olvasható volt az Új Zenei Szemle címủ folyóiratban. Kodály e cikk olvasása után határozta el, hogy meglátogatja Tarhost, mely meg is történt június 5-én. Szóban foglalta össze megelégedését: „Tarhos nagy jövő előtt áll.” (Gulyás, 1998, p. 66).

${ }^{20}$ Czövek Erna (Orsova, 1899. dec. 23. - Budapest 1983. márc. 30.), kiváló zongorapedagógus, jó nevű és hírű szakember, nem pártfunkcionárius. 1947-től, mint a Kultuszminisztérium tanácsosa, megszervezi a vidéki állami zeneiskolai hálózatot. 1934-től az Énekszó folyóirat munkatársa, rovatvezetője. 
Szokolay Sándor így emlékszik vissza az eseményre: „Van egy nagy szenzáció: itt van Kodály! Tegnap délben érkezett. A IV. líceummal elébe mentünk Csabára. Délután nagyszerű énekkari hangversenyt csaptunk, este balladaest volt a parkban. Kodály többször is vezényelt. Egy édes, aranyos, szerény és roppant szimpatikus bácsi. Ma (június 6-án) délután elmegy. Itt van vele Ádám Jenő is. Valószínű még zongorázni is fogunk, ha lesz idő. Tarhoson ilyen nagy ünnepség még nem volt!" (Szokolay, 2017, p. 175).

Az 1949/1950-es tanév két, ünnepségszámba menő látogatása és Novikov elismerő sorai megtették hatásukat. Már nem csak Békés-megye, hanem a minisztérium is kinyitotta a pénztárcáját és június 7-én megjelentek az Oktatásügyi Minisztérium képviselői, mérnökökkel együtt, hogy az iskola továbbfejlesztése érdekében helyszíni szemlét tartsanak.

Az építkezések, ha lassan is, de megindultak tehát. Az épületek fejlesztése mellett nagy gondja volt Gulyáséknak az iskolában tanuló diákok és tanárok létszámának alakítása is. A Zenepavilon felépítésére vonatkozó tervek egyre biztatóbban jelezték, hogy hamarosan új épülettel gazdagodik Tarhos. Viszont a kollégiumi elhelyezés sok gondot rótt az ottaniakra, és az sem volt sokáig tartható, hogy Tarhoson kiváltságos helyzetnek számított, ha egy tanárnak önálló szobája lehetett.

Az emeletráépítéssel kibővített nagykastély új állapotában csak enyhített a gondokon, de végleges eredményt nem hozott. Az egyetlen, tényleges megoldást jelentő átépítés, a konyha-ebédlő kialakítása volt, mely megoldott egy sor nehéz, étkeztetés körüli higiéniai és raktározási problémát (Gulyás, 1998, p. 64-68). A telefonösszeköttetés nehézsége viszont révbe ért: „Egy másik szenzáció: Tarhoson van telefon! A postának és az iskolának is lett nyilvános beszélője. Lassan kiépül Tarhos." - idézi fel a történteket Szokolay Sándor (Szokolay, 2017, p. 171).

A minisztérium is megkezdte a hangszerek szállítását, s a tanárok és tanulók nagy örömére 1951 tavaszán már tíznél több zongora volt az iskolában. A hangszerek beszerzése, az ének szaktanárképző beindítása mind azt mutatták, hogy az előző évek kitartó munkája eredményes volt. Ezzel egyidejűleg, sajnos, beszüntették a nyári énektanári és karvezetői tanfolyamot.

1951. augusztus 25-én az iskola teljes minőségében átkerült a VKM-től a Népművelési Minisztériumhoz. Ez az intézkedés látszólag a zene ügyében történt, ám valójában kárára volt a tarhosi iskolának. Végeredményben itt alig akadt akár egy ember is, akinek az általános oktatás, még inkább a nevelés szívügye lett volna (Gulyás, 1988, p. 92).

Az 1951/1952-es tanévig tartott a fiú tanulók Berkében ${ }^{21}$ való elszállásolása is, amikor visszaköltöztették őket a hosszú, parasztház küllemü, régen valószínű cselédlakásokként funkcionáló felújított kollégiumi épületbe. „Viszonylag tágas volt és jól felszerelt. Beüvegezett folyosó, angol WC.” - tudhatjuk meg Puskás Dezső tollából (Domokos, 2006, p. 56).

${ }^{21}$ Vadászház a Wenckheim birtokon. 


\section{Új zenetanárok, a Csellóosztály}

Később a gimnáziumi tanterv szükségessé tette, hogy felsőfokú végzettséggel is mủködjenek oktatók Tarhoson. A Zeneakadémia tanárai közül többen vállalták ezt, így került a Békés megyei kis településre például Holló Sándor, s 1951 novembere körül kereste fel Gulyást Friss Antal volt főiskolai csellótanár is azzal, hogy szívesen tanítaná a tarhosi diákságot. Így is lett. Egy év elteltével már úgy emlegették őket, mint a „csellóosztály”. Friss Antal körülvette magát tanítványaival, egymást hallhatták, egymást figyelték, s egymás sikereire mindig büszkék voltak, elismerték azokat (Gulyás, 1988, p. 74; F. Pálfy, 2002, p. 15).

„Tarhoson a nyári szünetben, augusztusban mi már előre megkezdtük a zenélést Friss Tóni bácsival - Papp Laci bácsi szervezésében 1953-ban, 54ben is. Tóni bácsi feleségével, Baby nénivel lejött Pestről két-három hétre, $\mathrm{s}$ egész nap folyt a cselló-gyakorlás, zenekarozás. Komoly haladást értünk így el, hiszen lényegesen meghosszabbodott a tanév. Minőségileg is komoly volt az előrehaladás. Gulyás Gyurka bácsi egy-egy csellódarabot lelkesen felvett az új magnóra a Zenepavilon nagyterme melletti új stúdióban." - emlékszik vissza Mező László ${ }^{22}$ volt tarhosi diák, a csellóosztály tagja (Domokos, 2006, p. 47).

Szintén tarhosi csellista volt Blaskovich Jenőné Szappanos Enikö ${ }^{23}$, aki következő gondolatait osztja meg velünk: „A csellistákat hét közben Paci bácsi, azaz Papp László tanár úr tanította, hét végén pedig lejött Budapestről hozzánk a Zeneakadémia tanára, Friss Antal, »Tóni bácsi«. A cselló osztály fantasztikusan összetartó banda volt. Ha otthonról kaptunk valami finomságot, megkínáltuk természetesen a többieket is. Ennél azonban sokkal többet ért, hogy jóban, rosszban segítettük egymást. (...) A Tóni bácsis cselló órákon majdnem mindenki itt volt. Körbeültük az éppen csellózót és minden hangot és szót elraktározva hallgattuk Tóni bácsi játékát és magyarázatát. Ha valaki nagyon szépen játszott, vagy megtanult egy ritka nehéz gyakorlatot, az jutalmul Tóni bácsitól 'Nobel díjat' kapott. Ez nem volt más, mint egy régi lyukas 2 filléres. A legtöbb Nobel díja természetesen Mező Lacinak volt. Ezeket fel lehetett füzni egy fonalra és nyaklánc helyett büszkén hordtuk." (Domokos, 2006, p. 109.).

A zenei rész tovább erősödött, mikor Tarhosra került több, országos hírü zenepedagógus: többek között Clementiszné Erőss Klára, Dános Lili, Teőke Mariann zongoratanár, Banda Márton, Vigh Árpád hegedűtanár s a fúvósok közül Hernádi Ferenc klarinétművész. Gulyás úgy gondolta, hogy ők lesznek a garanciái annak, hogy a Zeneakadémia felé a tarhosi diákoknak éppúgy megnyíljon az út, mint más szakiskolák tanulói számára (Gulyás, 1988, p. 75).

\footnotetext{
${ }^{22}$ Mező László: gordonkaművész. 1951-től Friss Antaltól gordonkát tanult először Tarhoson, később a budapesti Bartók szakiskolában és a Zeneművészeti Főiskolán (ma Zeneakadémia). 1963-től a ZF tanára és az Országos Filharmónia szólistája volt (Szabolcsi \& Tóth, 1975).

${ }^{23}$ Később a Ceglédi Erkel Ferenc Alapfokú Művészeti Iskola gordonka tanára.
} 


\section{Évzárók a Nagygödörben}

Az év legnagyobb eseményére (és egyéb jeles alkalmakra), az évzáróra, a néptáncegyüttes bemutatói mellett, balladákat tanultak be a tarhosi diákok. Mező Imre emlékeiből néhány gondolat: „Igen nagy hatást tett a remek, természet adta színpadon, a „Nagygödör”-ben, a terep adta lehetőségeket kihasználva, tábortüzek fényénél a „Bíró szép Anna” előadása.

$S$ a park esti csendjében megszólaltak a madrigálok, majd a kórus és a résztvevők közös éneke, amely nem elöre betanult müsorszám volt, hanem az esti csend és a hangulat ihletett bennünket az éneklésre (Domokos, 2006, p. 49).

\section{A legnehezebb évek és a Zenepavilon avatása}

Gulyás hosszas betegsége alatt (1951. március 28-tól 1952. március 9-ig) az iskolát átszervezték az 1952-ben bevezetésre kerülő zeneoktatási reform ${ }^{24}$ során. Az énekszak-tanítói képzést megszüntették és az iskola zenei gimnázium- és szakközépiskolaként müködött tovább. Nem engedték megnyitni a szaktanárképzőt sem, mondván, Tarhoson nincs megfelelő hangszeres képzés, holott az ország mindegyik zeneművészeti szakközépiskolája megnyithatta.

Az iskolában a tanárok elégedetlensége a tetőfokára hágott a lakás, fütés, élelmezési gondok miatt, 6 tanár kérte is elhelyezését, ami meg is történt (Gulyás, 1988, p. 78; Csende, 1976, pp. 69-76).

Elkezdődött a Zenepavilon építése is. Gulyás Magyarország zenei iskolavárosát álmodta meg Tarhoson, s remélte, hogy a Zenepavilont a többi pavilonépület is követi majd, a kollégium és a tanári lakások is felépülnek. „Az épület, amely az úgynevezett, gúnynevén »Sztálin-barokk« stílusjegyeit viseli, nem az első terv alapján készült. Az első terv egy igen szép, megnyerő megjelenésủ modern épületet ábrázol, amelyet magam is láttam egy minisztériumi látogatás során, tarhosiakkal, Gulyás Györggyel együtt. Sajnos, ezt a tervet nem fogadta el a minisztérium..." - Mező Imre emlékeiből idéztem (Domokos, 2006, p. 70).

A Zenepavilon avatására 1953. május 1-jén került sor. A tanulóifúság nagy erőkkel készülődött: sokat gyakoroltak a hangszeresek a megnyitó koncert miatt, de egyidejüleg a tanulók utat is építettek a Pavilonhoz, sőt, gyalogjárdát a cseresznyesor alá (Gulyás, 1998, p. 80, p. 87).

\section{A „Tarhosi per” és az iskola megszüntetése}

1953 januárjában elkezdődött - Gulyás szavaival élve - a „tarhosi per”. Hiszen „bőven akadt védő is és vádló is."

${ }^{24} \mathrm{Az}$ 1952-es zeneoktatási reform során hármas tagozódású iskolarendszert honosítottak meg: a zeneiskola - szakiskola - főiskola hármasában, az alapfokú zeneoktatástól eljutunk a magas fokú tanári, művészi és nem utolsó sorban, tudományos képzésig. (Parlando) 
1953. január 19-23. között a Népművelési Minisztérium Művészetoktatási Osztálya brigádvizsgálatot tartott Tarhoson. A vizsgálat értekezlettel kezdődött, melyen részt vettek a helybeli érdekeltek és a tanárok is. A bizottság feladata volt megvizsgálni, hogy a tarhosi, egyébként „feltűnően költséges képzés” tud-e valami többletet nyújtani, illetve, hogy a megye kulturális életében milyen szerepet tölt be az iskola? Ennek a Bizottságnak a „dialektikus és pártszerü" vizsgálatán múlott az, hogy Révai miniszter kollégiuma milyen határozatot hoz az iskola sorsát illetően. A Bizottság tagjainak megtiltották a véleménynyilvánítást, mondván, erre majd Pesten kerülhet csak sor. Nagy megdöbbenést szült ez mind az iskola tanárai, mind a megyei vezetők körében, hisz ők úgy gondolták, hogy a tárgyilagos véleményformálást csak közös megbeszélések és záró értekezlet segíthetné. Az iskola részéről mindenféle próbálkozásnak ellenálltak: szerették volna bemutatni a csellóosztályt, amely előmenetelére nagyon büszkék voltak, szorgalmazták a kórus meghallgatását, illetve hivatkoztak Novikov véleményére is, de a Bizottság elzárkózott a meghívások elől.

A Bizottság tagjai a tanárokat és a diákokat is nehéz helyzetbe hozták. A tanárokat arra biztatták, hogy menjenek máshova tanítani, a diákokat pedig arra agitálták, hogy foglalkozzanak csak közismereti tanulmányaikkal, mert nem fontos mindenkinek a zenei pálya, Tarhoson még sincs biztosítva további sorsuk, jövőjük. Ez meg is tette hatását. Sok tanár a látogatás után hetekig bizonytalan volt, a tanulók közül pedig többen úgy ítélték meg, hogy hasznosabb, ha csak közismereti tanulmányaikra koncentrálnak.

De vizsgálták az iskolának a megye kulturális életében betöltött szerepét is. Vidéken végeztek közvéleménykutatást arra vonatkozóan, hogy például „Szükséges magának Tarhos?” „furcsa” módja volt ez a vélemények feltérképezésének.

A januári brigádlátogatás felbolygatta az iskola békéjét, $\mathrm{s}$ mindenkit elkezdett nyugtalanítani saját sorsának alakulása és az intézmény jövője (Gulyás, 1998, pp. 82-86).

Végül a Bizottság olyan ellenséges, negatív anyagot állított össze Tarhosról, hogy azt Révai visszaadta a szakosztálynak átdolgozásra, arra hivatkozva, hogy nem elég szeretettel gondolták át és kezelték a dolgokat. Gyors munkájuk eredményeképpen, 1953. június 9-re elkészült az új jelentés és már ki is tüzték a kollégiumi ülést, ahol megvitatták Tarhos sorsát.

Révain kívül a párt prominens személyei vettek részt a tárgyaláson, valamint a Békés megyei pártbizottság részéről az akkori osztályvezető, a békési járási pártbizottság részéről a titkár, illetve a tarhosi iskola képviseletében Gulyás György, Mánya Éva és Ádám József iskolai párttitkár. Gulyásra nagy teher nehezedett a kollégiumi ülés alatt, hisz minden felmerülő napirendi pontra neki kellett válaszolnia a reggel 9-től délután fél 3-ig tartó összejövetelen, ahol csak úgy záporoztak a rosszindulatú kérdések és az egyre élesebb kirohanások.

A kollégiumi ülésről Révai József összefoglalója és a vizsgálóbizottság tagjainak állásfoglalásából a következő kép tárul elénk: 
Révai szerint a vizsgálóbizottság tagjainak alapvetően igaza volt, de ami jó Tarhoson, azt mindenképp át kell menteni, ápolni kell. Igazuk bizonyítékaként az iskolánál lévő „egészségtelen hangulatot” látta, melynek elsődleges felelőse Gulyás György és ezentúl minden egyéb felelősség csak járulékos. Gulyást felelősnek mondta ki többek között még a tanulók és szülők bevonásában az iskolai problémákba és iskolai ügyek kezelésébe, hogy az iskolai vezetés a megyei pártbizottsághoz fordult minden kisebb gonddal is és ezalatt úgy tüntették fel a minisztérium, illetve a főosztály részéről történt intézkedéseket, mintha valamilyen ellenséges munka folyna az iskola ellen. Révai kifogásolta, hogy az iskola 18 akkor végzett növendékéből senki nem akart más zenei intézményben továbbtanulni, hanem Tarhoson kívánták folytatni megkezdett munkájukat. Ez, Révai szerint, élesen szemben állt azzal a szellemmel, amely Tarhoson kirajzolódott, s egyébként pedig az a jó iskola, ahonnan elkívánkoznak a tanulók az utolsó évben. Makarenkói nevelési elvekre is hivatkozott, miszerint Makarenko is úgy nevelte a gyermekeket, hogy türelmetlenül várták az élet egyéb területén való munkálkodást az iskola után. Kifogásolta, hogy kirakatba tettékaz iskolát, hogy a pavilon-ünnepséget európaivá tették, holott a párt kultúrpolitikája a szerénység. A zenei nevelést is kritizálta: „zenei nevelésünk nem áll ott, ahol 10-15 év múlva állni fog, de hogy ez lenne az útja, az egy hamis beállítás volt" (Gulyás, 1998, p. 95). Leszögezte, hogy Tarhos nem alkalmas arra, hogy megoldja a gyerekek alsó-, közép- és felsőfokon való oktatását, a tehetséges parasztgyerekek oktatását. Azonban az iskola pozitív értékeit, mint énekkar, vagy a szolfézsoktatás, megtartják. Az iskolát viszont átköltöztetik Békéscsabára, s ehhez 5 év türelmi időt kaptak Gulyásék. Új elsős osztályt indítani nem lehet (Gulyás, 1998, pp. 93-96.).

A vizsgálóbizottság tagjainak (Rados Dezső, Antal György, Kadosa Pálné, Gulyás Mária, Mikusik Ârpád, dr. Cseh Jenőné, Tóth Ferenc és Baross Gábor) jelentéseiből a következő gondolatok kiemelése fontos:

Többen megfogalmazták, hogy a zeneelmélet és a szolfézs oktatása kiemelkedő, a kórusmunka magas nívójú, de a hangszeres oktatási gyakorlat messze elmarad az elméleti tantárgyak terén tapasztalt magas színvonaltól. Tarhoson azért vannak hangszerestanár-gondok, mert elszigetelt, nehezen megközelíthető helyen fekszik. Kifogásolták, hogy a tarhosi növendékek az iskola elvégzése után olyan helyet igényelnek maguknak a zenei életben, amire nem jogosultak és arra nem is lehetnek, hisz akkor feleslegesen indították volna a zeneakadémiai ötéves karvezető képzést. Tarhoson sokan továbbtanulni csak akkor szeretnének, ha indul Főiskola. Ez szintén elszigeteltté teszi a helyet és egy olyanfajta gőgről tesz tanúbizonyságot, amely semmilyen körülmények között nem támogatható.

Volt, aki a politikai munka alkalmatlanságáról jelentett, miszerint a helyi pártszervezet nem gyakorolja megfelelően munkakörét, így kritikát például az igazgató, vagy a DISZ felé. „A hibák külső okának a tarhosi elszigeteltséget tartom, amit jelen körülmények közt népi demokráciánk nem is tud csökkenteni." (Gulyás, 1998, p. 98). 
Gulyást szintén több ízben érte kritika a jelentések alkalmával: „Teljhatalmú ura” Tarhosnak, aki „nyomásként nehezedik” környezetére, tanárokkal „nem megfelelö" hangot használ. A tanárok nem mernek semmilyen ellenvetést megfogalmazni Gulyással szemben, s félnek négyszemközt beszélgetni. Sokan kérik rövid időn belül az áthelyezésüket, ezért változik évenként a tantestület. Egy másik referens arról ír, hogy úgy félnek a tanárok az igazgatótól, hogy még áthelyezésüket sem merik kérni.

Olyan „veszélyes” jelenségeket is megfogalmaznak, mint hogy a spontán alakult Tarhos nem beilleszthető az egységes zeneoktatási rendszerbe, Tarhos kasztnak tünik, s ez abból is látszik, hogy főiskola létrehozását követelik, illetve az azon való aggódásból, hogy mi lesz az ország tehetséges parasztgyerekeivel, ha esetleg nem lesz Tarhos.

A tanárok és diákok között érezhetően jelenlévő pánikhangulat fentebbi okai mellett az a félrevezetés is áll, hogy a diákok félre lettek tájékoztatva afelől, hogy tanulmányaikat Tarhoson folytathatják, s mint vezető zenei káderek kerülnek ki az intézményből. Kritikaként fogalmazták meg a tanulók megválogatását, mert többről kiderült, hogy még középszerű zenésznek sem alkalmasak. Az alsófokú oktatás produktivitását is megkérdőjelezték.

Helytelenítették a nagy költségvetéssel létrejött iskola megszületését, hisz ezzel nagy beruházást okoztak az államnak, vizsgálat kiírását szorgalmazzák ez ügyben. Olyan formát javasolnak az iskolának, amely megfelelően beilleszkedne az ország zeneoktatási rendszerébe.

$S$ ugyan Békés-Tarhos azzal a szándékkal lett létrehozva, hogy a Békés megyei szegény sorsú gyerekeket karolja fel, csak kevesebb mint fele a tanulóknak békési, a többiek az ország minden tájékáról jöttek. Ráadásul Békés megye sem profitál az iskola létezéséből, holott az iskolai kórus országos viszonylatban az elsők között található. Az iskola elszigetelten, önmagában él (Gulyás, 1998, pp. 97-102).

Gulyást a miniszteri kollégium kötelezte, hogy ismertesse a határozatot a tanári karral, de ne úgy, mint minisztériumi döntés, hanem mint perspektíva. Június 11-én már meg is tartotta a beszámolót, de nem az elvárásoknak megfelelően, melyről írásbeli értékelés is született Révainak, miszerint Gulyás nem készítette eléggé elő az előadását, az önkritika vérszegény volt, $\mathrm{s}$ a tarhosi tanárokat valószínű egyáltalán nem érdekelte Tarhos sorsa, mert egyetlen hozzászólás sem hangzott el a beszámoló után. Különösen a kollégiumi ülésen résztvevőknek volt nehéz dolguk perspektívaként képviselni az ott elhangzottakat. Tele voltak kétségekkel, de már biztató jeleket is lehetett észlelni.

A Pavilonavatás után ismét sürüsödtek a látogatások mind az újságok, mind más intézmények részéről. Tarhost kezdték újra felfedezni, amit jó jelnek vettek Gulyásék. J. Ty. Leszjuk látogatását kell kiemelni ezekből az időkből, mert komoly visszhangja volt a minisztériumban (Révai helyett Darvas József volt már a népművelési miniszter). Leszjuk a moszkvai kulturális minisztérium munkatársaként érkezett, és meglátogatta a tarhosi iskolát is. A 
Szabad Nép március 11-i számában nyilatkozott a magyarországi tapasztalatairól, melyben tarhosi látogatásáról is szólt, nagyon pozitívan: dicsérte az egyébként nagyon tehetséges tanítványok és tanárok kollektíváját, az iskola kórusát, akik oly tökéletességgel szóltak, s énekükből úgy érződött a szovjet-magyar barátság, mintha szovjet kórusokat hallott volna. A hangszeres müvészeket is magasztalta, s megállapította, hogy minden eredmény annak a nagyszerü nevelőmunkának és kiváló körülménynek az eredménye, amit a békés-tarhosi iskola nyújt. Majd így zárta: „Ez a nagyszerű intézmény bármely országnak méltán becsületére válnék." Érthető tehát, hogy ezek után Gulyás nagy reményekkel utazott fel Budapestre az érte küldött minisztériumi kocsival.

De, sajnos, nem kapott végleges és megnyugtató választ Tarhos jövőjével kapcsolatban, nem módosították a kollégiumi határozatokat. Azonban a miniszter segíteni akart, s a beszélgetésen többek között előkerült, hogy Tarhos jó helyen van, nem lenne jó áttelepíteni, mert nevelési vonatkozásban elveszítené, ami most a sajátja. Ilyen viharos események közepette lassan 1953ban is lezajlottak a vizsgák és megtartották az 1952/1953-as tanév évzáróját.

Az utolsó évről Gulyásnak nagyon kevés emléke maradt. A rendben megtartott évzáró után mintegy átverésként lejött a minisztériumi szakosztály költségvetési előadója, hogy állítsák össze az iskola teljes kiépítésének igényét. Gulyás nem vette észre, hogy ez csak azért történt, hogy vele bizonyítsák a várható beruházások nagy összegét akkor, mikor egyébként komoly gazdasági megszorításokat léptettek életbe országszerte. A tervek nem valósultak meg.

A megszünés csendben történt. Nem adta hírül a rádió, nem hozták le az újságok. A tanároknak egy rövid tanári kari gyülésen lett kihirdetve, míg a gyerekeknek értesítőket küldtek ki, 1954. augusztus 31-én (Gulyás, 1998, p. 106-112). A megszüntetés évében már 43 zongorista, 40 hegedűs, 23 csellista, 12 fuvolista, 19 klarinétos, 11 rézfúvós, vagyis összesen 148 hangszeres tanulója volt a tarhosi iskolának (Gulyás, 1988, p. 51).

A semmiből megszületett iskola igazgatójának sikerült egy olyan intézményt létrehoznia, mely 8 éves müködése alatt bebizonyította, hogy vidéken is lehet értéket teremteni és európaivá válni. „Az egykori Énekiskola 2007ben Magyar Örökség díjat kapott, 2016 tavaszán kuratóriumi döntés során a Nemzeti Értéktárba került." (Dombi, 2016).

\section{Irodalom}

Csende, B. (1976). Békés-Tarhos. Békés városi tanács végrehajtó bizottsága.

Dombi Józsefné Kemény, E. (2016). Békés-Tarhos múlja és jövője. Parlando, 58(4), http://www.parlando.hu/2016/2016-4/Dombine-BekesTarhos.htm

Domokos Attiláné Farkas, M., Mező, I. Pallosné Rozgonyi, P. (2006, Eds.). BékésTarhos 1946-1954. Békés. 
E. Kovács, K. (1949). A Tarhosi Énekiskola, In (sz.n.) Szemtanu (pp. 70-99). Athenaeum.

F. Pálfy, Zs. (2002). Békés-tarhosi nyitott könyv. Békés.

Farkas, L. (2016). 100 éve született Gulyás György. Békés-Tarhosi Kalendárium. Kiadó hiányzik.

Gulyás, Gy. (1988). Büneim... Büneim? Békés.

Gyarmath, O. (2001). Tudsz-e Tarhosért lelkesedéssel dolgozni? Békés.

Horváth, E. (2002). A Sárospataki Református Kollégium, mint a magyar népfőiskolai mozgalom otthonteremtője. In Dienes, D. \& Szabadi, I. (Eds.), Doctrina et Pietas - Tanulmányok a 70 éves Barcza József tiszteletére (pp. 133-142). DebrecenSárospatak.Kedves, T. (2004, Ed.). A magyar zenemüvészetért. Válogatott írások és képek Gulyás György hagyatékából. Debrecen.

Keresztúry, D. (1975). Levéltöredék. Muzsika. 1975. április https://adtplus.arcanum. hu/hu/view/Muzsika_1975/?pg=156\&layout=s (2020. 12. 16.)Knausz, I. (1985). A szocialista közoktatás-politika kialakitásának első kísérletei Magyarországon a felszabadulás után. doktori disszertáció http://mek.oszk.hu/13600/13616/ pdf/13616.pdf (2020. 08. 24.)

Kodály, Z. (1943, Ed.). Iskolai Énekgyüjtemény I. Országos Közoktatási Tanács.

Kodály, Z. (1974). Visszatekintés. Zenemükiadó Vállalat.

Romsics, I. (2005). Magyarország története a XX. században. Osiris Kiadó.

Romsics, I. (2010, Ed.). Magyarország története. Akadémiai Kiadó.

S. Turcsányi, I. (2011). Dokumentumok a Békés-Tarhosi Énekiskola (19461954) életéről Dr. Gyarmath Olga hagyatékában. A Békés megyei múzeumok közleményei 34. 311-347. https://library.hungaricana.hu/ hu/view/MEGY_BEKE_BMMK_34/?query=AUTI1\%3D(S)\%20OR\%20 BKMK1\%3D(S)\&pg=314\&layout=s (2020. 08. 03.)

Surányi, I. (2005). Alapfokú (általános iskolai) oktatás Székesfehérváron 19451948 között. Neveléstörténet, (2)3-4, 112-150. http://www.kodolanyi.hu/ nevelestortenet $/$ act $=$ menu_tart\&rovat_ $\bmod =\operatorname{archiv} \&$ eid $=32 \& \mathrm{rid}=1 \& \mathrm{id}=171$

Szabolcsi, B. \& Tóth, A. (1965). Zenei lexikon. Zeneműkiadó Vállalat.

Szokolay, S. (2017). Hogy is kezdődött?... Levelek a diákévekből. Legend Art Kiadó.

https://www.parlando.hu/2016/2016-1/2016-kerek.pdf (2020. 07. 23.)

https://www.parlando.hu/2018/2018-3/Bardos-reszlet.pdf (2020. 07. 27.)

http://www.parlando.hu/Elokeszito605.htm (2020. 12. 17.) 


\section{Mellékletek}

\section{1. melléklet}

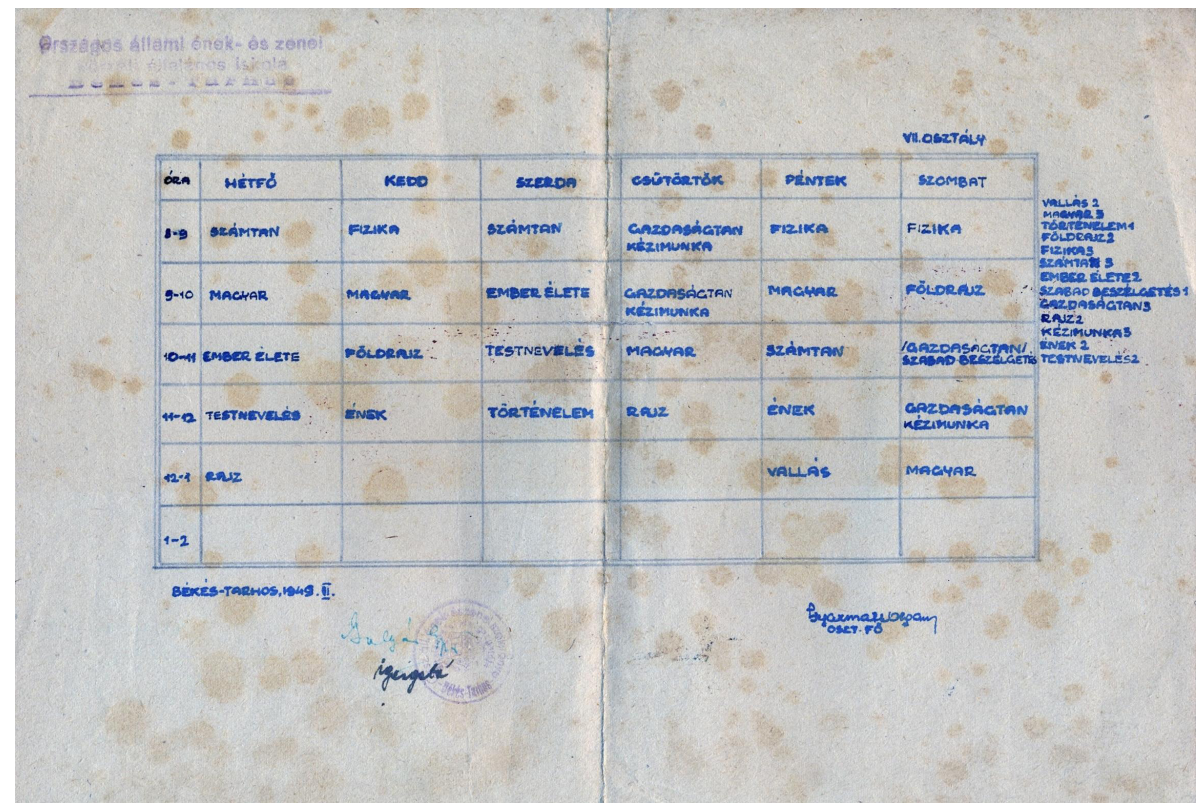

forrás: Békési Jantyik Mátyás Múzeum anyaga 


\section{2. melléklet}

\begin{tabular}{|c|c|c|c|c|c|c|c|c|}
\hline A tantárgyak neve & II. & III. & III. & IV. & V. & VI. & VII. & VIII. \\
\hline Hit- és erkōlcstan & 2 & 2 & 2 & 2 & 2 & 2 & 2 & 2 \\
\hline Magyar nyelv és irodalom & 10 & 11 & 13 & 14 & 6 & 6 & 5 & 5 \\
\hline Tōrténelem & - & - & - & - & 2 & 2 & 2 & 2 \\
\hline Fōldrajz és néprajz & - & - & - & - & 3 & 3 & 2 & 2 \\
\hline Az ember élete & - & - & - & - & - & - & 2 & 2 \\
\hline Természetrajz & - & - & - & - & 2 & 2 & - & - \\
\hline Természettan & - & - & - & - & - & - & 3 & - \\
\hline Vegytan & - & - & - & - & - & - & - & 3 \\
\hline Számolás és mérés & 5 & 5 & 5 & 5 & 3 & 3 & 3 & 3 \\
\hline Rajzolás & - & 2 & 2 & 2 & 2 & 2 & 2 & 2 \\
\hline Ének & 2 & 2 & 2 & 2 & 2 & 2 & 2 & 2 \\
\hline Testnevelés & 2 & 2 & 2 & 2 & 2 & 2 & 2 & 2 \\
\hline Szabad beszélgetés & - & - & - & - & 1 & 1 & 1 & 1 \\
\hline A kōzōs tárgyak óraszáma: & 21 & 24 & 26 & 27 & 25 & 25 & 26 & 26 \\
\hline A választható tárgyak óraszáma: & - & - & - & - & 6 & 6 & 6 & 6 \\
\hline Heti óraszámok & - & - & - & - & 3 & 3 & 3 & 3 \\
\hline \multicolumn{9}{|l|}{ Válas ztható tantárgyak és gyakorlatok } \\
\hline Gazdasági gyakorlatok & - & - & - & - & 3 & 3 & 3 & 3 \\
\hline Mühelygyakorlatok & - & - & - & - & 3 & 3 & 3 & 3 \\
\hline $\begin{array}{l}\text { Kereskedelmi gyakorlatok, } \\
\text { gyorsírás }\end{array}$ & - & - & - & - & 3 & 3 & 3 & 3 \\
\hline Háztartási gyakorlatok & - & - & - & - & 3 & 3 & 3 & 3 \\
\hline $\begin{array}{l}\text { Elố idegen nyelv (angol, francia, } \\
\text { német, olasz, orosz) }\end{array}$ & - & - & - & - & 3 & 3 & 3 & 3 \\
\hline Latin nyelv* & - & - & - & - & 3 & 3 & 3 & 3 \\
\hline Társas ének és zene & & & & & 3 & 3 & 3 & 3 \\
\hline Mértani rajz & - & - & - & - & 2 & 2 & 2 & 2 \\
\hline
\end{tabular}

forrás: http://www.kodolanyi.hu/nevelestortenet/?act=menu_tartErovat_ mod $=$ archivEeid $=32$ Erid $=1$ Eid $=171$ 


\section{Dévai, A.}

\section{Once upon a time in Békés-Tarhos}

In 1946, a choral school was established in the town of Tarhos, Békés county, Hungary, and it achieved worldwide fame, even though it existed only for a short time, until 1954. Following a brief overview of the school's historical background, I outline the struggles overcome by the school's director, György Gulyás, while establishing this institution. The creation of the necessary conditions for the school's operation involved a number of challenges: throughout the nine years of its existence, teaching at the school encountered considerable difficulties. In addition to the constant shortage of rooms, problems in finding adequate accommodation for students and teachers, food shortages, inadequate equipment, and so on, political attacks and the uncertainty of Tarhos's future were constant concerns for the school's director and management. My study reveals the essential, historical facts, based on a timeline from the school's foundation to its closure. Over and above the many obstacles, those in the school took part in numerous fine and memorable events, such as the concert for the Congress of World Youth, radio broadcasts, visits by famous composers, the construction and opening of the Music Pavilion, and Zoltán Kodály's visit to the premises. The Tarhos School's exciting and eventful life has been examined by such experts as Béla Csendes, Zsuzsanna F. Pálfy, György Gulyás, Olga Gyarmath and Zoltán Kodály. It is therefore not my intention to present the legend and mission of the Tarhos School, nor to detail the unique and high-quality musical education provided by the school, or its achievements. My research is based on the available literature in Hungarian articles and journals and on internet materials.

Keywords: Gulyás György, Tarhos, Békés-Tarhos, music school

Dévai Adrienn: https://orcid.org/0000-0003-4351-9139 